\title{
Note
}

\section{Drought susceptibility and xylem dysfunction in seedlings of 4 European oak species}

\author{
KH Higgs, V Wood \\ Horticulture Research International, East Malling, West Malling, Kent ME19 6BJ, UK
}

(Received 23 June 1994; accepted 8 March 1995)

\begin{abstract}
Summary - Seedlings of oak (Quercus robur, Q petraea, $Q$ cerris and $Q$ pubescens) were subjected to drought in pots to compare drought susceptibility in these contrasting species. Hydraulic dysfunction of the xylem vessels in petioles of seedlings was determined as the amount of air embolism that occurred under varying water potential $(\Psi)$. Curves relating vulnerability to xylem embolism with $\Psi$ revealed that $Q$ robur was more vulnerable than the other species examined. A loss of about $40 \%$ in petiole conductivity occurred at a xylem water potential of about $-3.0 \mathrm{MPa}$ in $Q$ robur, $-3.9 \mathrm{MPa}$ in $Q$ petraea, $-3.7 \mathrm{MPa}$ in $Q$ pubescens and less than $-4 \mathrm{MPa}$ in $Q$ cerris. Detection of cavitation events by acoustic emission (AE) failed to distinguish between species and AE did not increase until $\Psi$ was less than $-3 \mathrm{MPa}$.
\end{abstract}

\section{oak / water relations / xylem embolism / drought}

Résumé - Sensibilité à la sécheresse et dysfonctionnement xylémique chez les semis de 4 espèces de chênes européens. Des semis de chêne (Quercus robur, $Q$ petraea, $Q$ cerris et $Q$ pubescens) ont été soumis à une sécheresse en pots afin de comparer la sensibilité à la sécheresse de ces différentes espèces. Le dysfonctionnement hydraulique des vaisseaux du xylème dans les pétioles des plants a été déterminé par la quantité d'embolie apparaissant pour différentes valeurs du potentiel hydrique foliaire $(\Psi)$. Les courbes reliant $\Psi$ avec la vulnérabilité du xylème à l'embolie ont révélé que $\mathrm{Q}$ robur est plus vuinérable que les autres espèces étudiées. Une perte d'environ $40 \%$ de la conductivité pétiolaire est apparue pour un potentiel hydrique du xylème d'environ $-3,0 \mathrm{MPa}$ chez $\mathrm{Q}$ robur, $-3,9 \mathrm{MPa}$ chez $\mathrm{Q}$ petraea, $-3,7 \mathrm{MPa}$ chez $\mathrm{Q}$ pubescens, et inférieur à $-4 \mathrm{MPa}$ chez $\mathrm{Q}$ cerris. $\mathrm{La}$ détection des phénomènes de cavitation par émission acoustique (AE) n'a pas permis de distinguer les espèces, et (AE) n'augmentait plus quand $\Psi$ descendait en-dessous de $-3 \mathrm{MPa}$.

chêne / relations hydriques / embolie du xylème / sécheresse 


\section{INTRODUCTION}

Oak has experienced recurrent decline during this century in Europe with numerous trees either dead or large areas exhibiting dieback symptoms and poor foliage condition, leading to a general weakening of trees (OEPP/EPPO, 1990). An increased incidence in eastern Europe in the 1980s has been of concern following the 1976 drought, affecting Quercus robur in particular. Although there is no general decline in the UK, local dieback has occurred in oak from the 1920s. A survey in 1987 in the UK has shown that $18 \%$ of oak trees had less than $10 \%$ crown dieback, with the southeast being worst affected (Hull and Gibbs, 1991). Various causes have been suggested, but recent dieback in Europe has been associated with drought (Delatour, 1990; Vannini and Scarascia Mugnozza, 1991; Grieg, 1992), with Quercus robur being most severely affected (Delatour, 1990). It is important to quantify susceptibility to drought in order to examine its implications in dieback symptoms. A susceptible species loses hydraulic integrity of the stem or shoots through xylem vessels cavitating during a normal diurnal course of water potential and then becoming embolised, or airfilled. These cavitation events may accumulate embolisms and reduce xylem transport severely, leading to eventual dieback of the shoot. In contrast, more hardy species may be able to maintain xylem flow with few cavitation events occurring under the same stress conditions. A useful measure of drought susceptibility is, therefore, to define the relationship between loss of hydraulic conductivity and water potential (Tyree and Sperry, 1989). Unfortunately, this method only gives a measure of readily reversible embolisms and does not fully take into account tyloses caused by previous stress excursions and other causes of embolism (eg, winter freezing/thawing). A method to detect cavitation events in the stem as they occur is also needed. The acoustic emission technique would seem to provide such a method as it is designed to detect tiny acoustic signals emitted by vessels as they cavitate (Dixon et al, 1984; Borghetti et al, 1989; Tyree and Sperry, 1989). The work described here examined drought susceptibility at the seedling stage in 4 species of oak - Quercus robur, $Q$ petraea, $Q$ cerris and $Q$ pubescens - and was designed to complement work by other groups (Vannini and Scarascia Mugnozza, 1991; Cochard et al, 1992) on mature trees. The first 2 species are mesic, mid-European, and are widespread in the United Kingdom, while the other 2 are more xeric, drought resistant species, commonly found in southern Europe and therefore provide a perceived range in drought susceptibility. In this research, drought susceptibility was compared in potted seedlings of the 4 species using the techniques of acoustic emission and hydraulic conductivity. It is important to know whether drought susceptibility is inherent as the seedling stage of growth or whether it is a characteristic that develops as trees mature.

\section{MATERIALS AND METHODS}

Seeds of Quercus robur, $Q$ petraea and $Q$ pubescens, all from a French provenance, were germinated in November 1990 to provide seedlings for use in 1992 and 1993. In addition, plants of $Q$ robur, $Q$ petraea and $Q$ cerris, purchased in root trainers, were potted for use in 1992 and 1993. Two groups of 10 plants each, chosen from 2 of the 4 species, were droughted for periods of about 1 week at a time during July and August 1992, in a polytunnel. Measurements of acoustic emission and $\Psi$ were made on selected plants during the drought period. Petioles were sampled for hydraulic conductivity $\left(L_{p}\right)$ measurements using the method of Sperry et al (1988a). Each leaf was cut from its stem under degassed water and its petiole excised from the base of the leaf lamina hefore cutting to a length of $20 \mathrm{~mm}$. All operations were done under degassed water. The petiole was wrapped in 
PTFE tape to increase its diameter sufficient to fit a tubing manifold. The manifold was able to take 15 petioles and was connected to a head of degassed and filtered $(0.2 \mu \mathrm{m})$ oxalic acid $(0.1 \%)$. Under a pressure head of $6 \mathrm{kPa}$, the rate of flow through each petiole was measured in turn by discharge onto a microbalance. After pressurising all samples simultaneously at $175 \mathrm{kPa}$ for $10-15$ min to dissolve air in vessels, the flow rate was remeasured under $6 \mathrm{kPa}$ pressure. The difference between the initial and final flow rates was expressed as a percentage of the latter to give the loss in $L_{p}(\%)$.

During 1993, $L_{p}$ measurements were made on petioles from excised main stems or branches that had been allowed to dehydrate in the laboratory to the required $\Psi$. Stems were kept in humidified black polyethylene sacks overnight to equilibrate (Tyree et al, 1992). On the following day, petioles were sampled as just described from current-year wood for $L_{p}$ measurement.

Acoustic emission (AE) was measured using 3 sensors to detect signals in the $100-300 \mathrm{kHz}$ range (115I, Physical Acoustics Ltd, Cambridge, UK). Two sensors were connected to a 2-channel amplifier system, of a design similar to that of Sandford and Grace (1985). The 3rd sensor was connected to a single-channel signal processor (model 4615 Drought Stress Monitor, Physical Acoustics Ltd, Cambridge, UK) set at a gain of $60 \mathrm{~dB}$. Both signal conditioning amplifiers were modified to provide $0-5 \mathrm{~V}$ event outputs to a data logger. Most AE events occurred between 0600 and $1600 \mathrm{~h}$ (GMT). Each sensor was attached to the main stem of the plant with a spring-loaded perspex holder, the precision spring providing a force of $40 \mathrm{~N}$ when compressed to a specified length. No bark was removed unless the surface was rough, in which case the surface was lightly scraped to remove irregularities. Nontoxic silicon grease was applied between the sensor and the bark to improve acoustic contact.

Linear differential variable transformers (LVDTs) were mounted in metal frames (Higgs and Jones, 1984) and used to continuously monitor variations in stem diameter concurrently with $A E$ measurements. They were operated from a stabilised $10 \mathrm{~V}$ DC supply and had a maximum stroke of $\pm 5 \mathrm{~mm}$ (type DG/5 mm, Sangamo, Schlumberger, Bognor Regis, UK).

\section{RESULTS}

Vulnerability curves are presented for 1993 data in figure 1. Data for 1992 were similar but more scattered. There were no discernible differences between seedlings grown from seed or bought in root trainers. Each point is the mean of determinations for 2 petioles. Lines were fitted by linear regression using the transformed response

Table I. Regression coefficients from linear regressions of maximum hydraulic conductivity $(\mathrm{kg} \mathrm{m}$ $\mathrm{s}^{-1} \mathrm{MPa}^{-1}$ ) on leaf area $\left(\mathrm{m}^{2}\right)$.

$\begin{array}{ccc}\text { Slope } & \text { Intercept } & R^{2} \\ \left(\times 10^{-4}\right) & \left(x 10^{-7}\right) & \end{array}$

$\begin{array}{lllll}\begin{array}{llll}\text { robur } \\ (n=79)\end{array} & \text { estimate } & 2.1 & -2.4 & 0.625 \\ & \text { SE } & 0.19 & 0.67 & \\ \begin{array}{l}\text { Q petraea } \\ (n=94)\end{array} & \text { estimate } & 2.3 & -2.3 & 0.586 \\ & \text { SE } & 0.20 & 0.75 & \\ Q \text { cerris } & \text { estimate } & 1.5 & -1.0 & 0.661 \\ (n=68) & \text { SE } & 0.13 & 0.31 & \\ & & & & 0.573 \\ Q \text { pubescens } & \text { estimate } & 0.7 & 0.2 & \\ (n=67) & \text { SE } & 0.08 & 0.20 & \end{array}$


variable: $\left.\log \left[L_{p}+0.5\right) /\left(100-L_{p}+0.5\right)\right]$. This is the empirical logit transformation for percentage data (2.1.6; Cox and Snell, 1989). The value of 0.5 added to the numerator and denominator ensures that the transformation is properly defined when $L_{p}$ is 0 or $100 \%$. Regression analysis showed that the line for $Q$ robur was different from that of each of the other species $(P<0.01)$. The point at which $40 \%$ loss in $L_{p}$ occurred (with upper and lower $95 \%$ confidence limits) was at the following xylem water potentials: -3.0 $\mathrm{MPa}(-2.5,-3.7)$ for $Q$ robur, $-3.9 \mathrm{MPa}$ $(-3.3,-5.2)$ for $Q$ petraea, $-3.7 \mathrm{MPa}(-3.3$, -4.2) for $Q$ pubescens and $-4.9 \mathrm{MPa}(-3.9$, -7.7) for $Q$ cerris; imprecision in this latter case was due to paucity of data in this region. Maximum $L_{p}$ in petioles (ie, with all embolisms dissolved) was linearly related to leaf area (table I). Regressions were not constrained through the origin. The slope
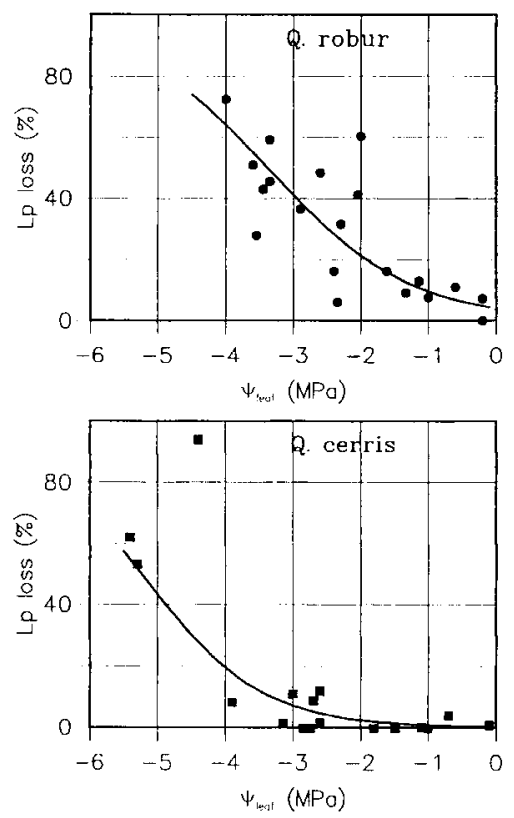

of each fitted line provides an estimate of LSC and it is noted that $Q$ pubescens exhibited the lowest LSC, $Q$ robur and $Q$ petraea the highest with Quercus cerns in between.

When AE from stems were determined for potted seedlings, there were no observed species differences. Regression of log AE on $\Psi$ revealed no relationship between these variables $\left(R^{2}=0.11\right)$. Acoustic emissions tended to increase in response to drought but not until $\Psi$ reached about -3 to $-4 \mathrm{MPa}$. There were periods when AEs were produced abundantly and periods when there were almost none. This is illustrated in figure 2 for a plant entering a drought phase after being without water for its 2 nd day ( 30 May). Many AEs were produced between about 0800-1100 $\mathrm{h}$ on 30 May but few for the remainder of the day, despite similar levels of photon irradiance (Ip). Photon irradiance was similar on the following day $(850 \mathrm{com}$ -
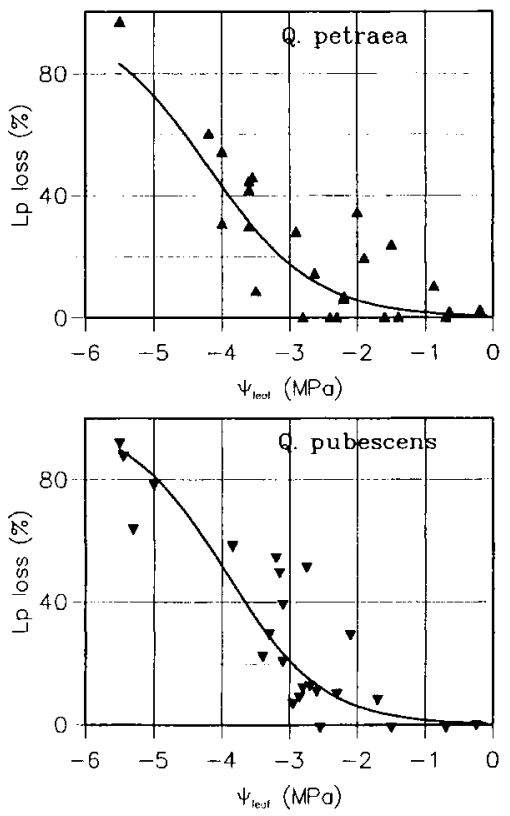

Fig 1. Vulnerability to embolism in each of 4 Quercus species. $L_{p}$ loss is percent loss in hydraulic conductivity and $\Psi_{\text {leaf }}$ is leaf water potential. Curves were fitted by linear regression using the transformed response variable $\log \left[\left(L_{p}+0.5\right) /\left(100-L_{p}+0.5\right)\right]$. 
pared with $910 \mu \mathrm{mol} \mathrm{m}-2 \mathrm{~s}^{-1}$ on 30 May, averaged from 1000-1600 h) but there were few AEs produced, despite a slightly greater vapour pressure deficit (1.2 and $2.0 \mathrm{kPa}$ over the same periods). The time course of stem diameter change (fig 3 ) shows that more water was being withdrawn from stem tissues on 31 May then on the previous day, but fewer vessels were producing AEs in response.

\section{DISCUSSION}

It is important to know whether drought susceptibility is inherent at the seedling stage of growth or whether it is a characteristic that develops as trees mature. Vulnerability curves derived from measurements on potted seedlings have shown that even in this young material, Quercus robur is more vulnerable to embolism formation due to water stress than other species examined here. Xylem water potential may fall to $-2 \mathrm{MPa}$ in $Q$ robur, or $-3 \mathrm{MPa}$ in the other species, before $20 \%$ or more of the conducting tissue in petioles becomes embolised. This agrees with data obtained by Cochard et al (1992) on petioles of 2- to 4-year-old branches of mature $Q$ petraea, $Q$ pubescens and $Q$ robur. The leaf specific conductances reported here are lower than those deduced from figure 4 in Cochard et al (1992). How-
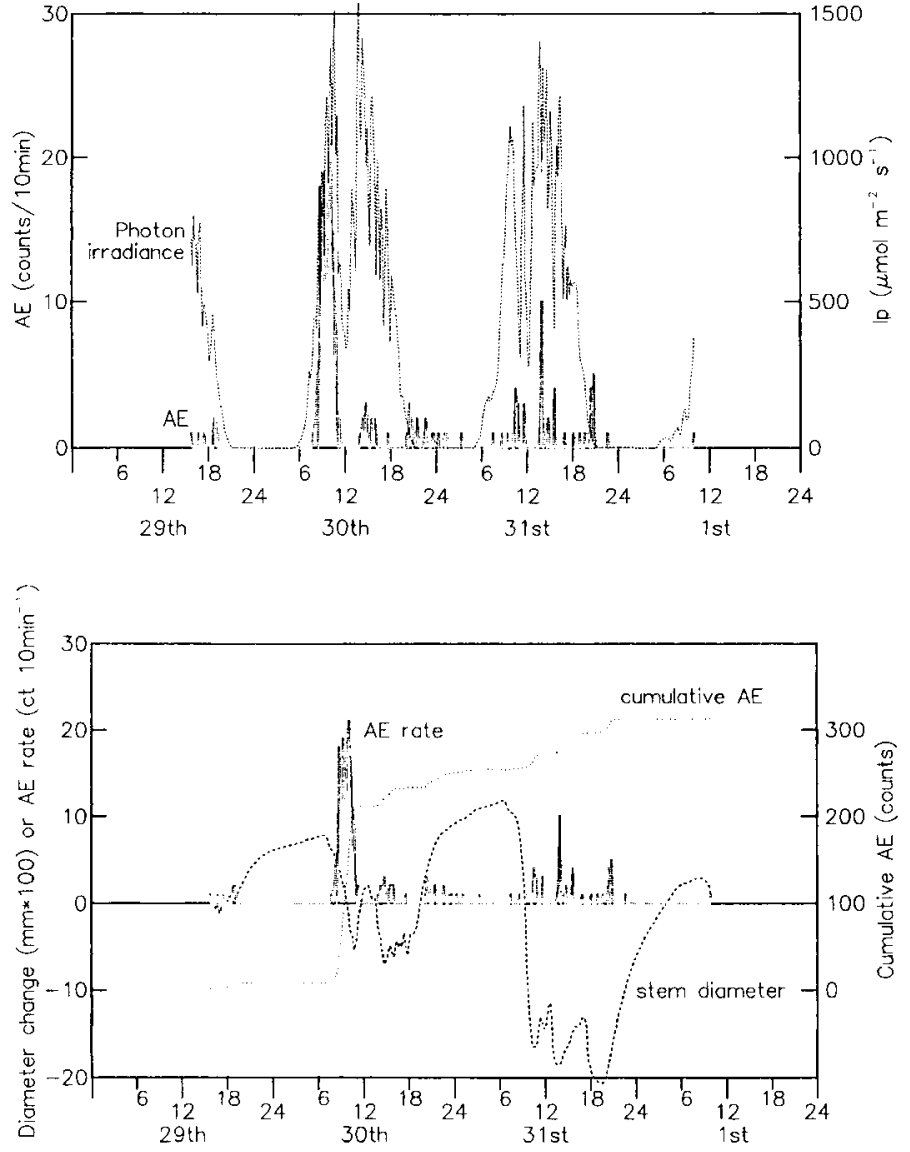

Fig 2. Example trace of photon irradiance (Ip) and acoustic emission (AE) rate over 2 full days in May 1992 in a polytunnel. Dashed line = photon irradiance; solid line $=$ acoustic emission.
Fig 3. Same acoustic emission (AE) rate as in figure 2 but with cumulative $A E$ (dots) and stem diameter (dashes) added. 
ever, LSC for petioles of oak species have to be treated with caution as the petioles are very short (2-5 $\mathrm{mm}$ in these species) and have to be excised from the leaf lamina. It may not be appropriate, therefore, to relate conductivity in a petiole sample to the whole leaf area subtended by it. These workers also found little difference in vulnerability between petioles and 1-year shoots in these species.

In the United Kingdom, $\Psi$ regularly cycles between near 0 and $-1.5 \mathrm{MPa}$ in young seedlings (Higgs, unpublished results). Over this range, a level of embolism less than $20 \%$ would be generated. However, $\Psi$ in Quercus seedlings does occasionally fall below -2 MPa due to prevailing evaporative demand and may fall further in young transplants in need of irrigation. In these cases, embolism will be increased beyond $20 \%$, possibly affecting growth and causing leaves to fall. If vulnerability in seedling stems is similar to that in petioles, then winter freezing and thawing will further increase embolism (Sperry et al, 1988b; Sperry and Sullivan, 1992). This reduced hydraulic sufficiency could prove critical to the plant's survival if conditions are not suitable for xylem regrowth in the following spring or if root initiation has not proceeded fast enough.

An important factor in determining a plant's ability to avoid damaging levels of embolism is the amount of stomatal control over $\Psi$. It has been observed for droughting Quercus seedlings growing in the field that there was a wide range in $g_{\mathrm{S}}(40-400 \mathrm{mmol}$ $\mathrm{m}^{-2} \mathrm{~s}^{-1}$ ), but when $\Psi$ fell below -1.5 to -2.5 $\mathrm{MPa}$, the range in $\mathrm{g}_{\mathrm{s}}$ was reduced from 80 $\mathrm{mmol} \mathrm{m} \mathrm{m}^{-2} \mathrm{~s}^{-1}$ to near 0 , suggesting that $\Psi$ was controlling $\mathrm{g}_{\mathrm{s}}$ (Higgs, data not presented). There were no observed differences between $Q$ robur, $Q$ petraea and $Q$ cerris in the relationship between $g_{s}$ and $\Psi$. A similar relationship was obtained between $g_{\mathrm{s}}$ and pre-dawn $\Psi$ in adult $Q$ petraea and $Q$ robur, with no species differences (Bréda et al, 1993). At these lower values of $\Psi$, the closing of stomata prevents development of embolism beyond $20-30 \%$ in $Q$ robur by halting further decline in $\Psi$. It has been argued, however, that it may be beneficial for some conducting vessels to be lost through cavitation to maximise $\mathrm{g}_{\mathrm{s}}$, and hence production, allowing for a 'working level' of embolism (Jones and Sutherland, 1991). It has been shown in Betula occidentalis that reduction in stem $L_{p}$ can lead to short-term reduction in $\mathrm{g}_{\mathrm{s}}$ and transpiration rate with no reduction in $\Psi$ (Sperry and Pockman, 1993). Although this limits productivity, the alternative is dieback of the crown due to cavitation and embolism. This has yet to be tested for Quercus species.

The use of acoustic techniques to detect cavitations has not yielded promising results in this trial. The illustrative data in figure 2 show that AEs may start when water is being withdrawn from tissues rather than when $\Psi$ reaches a low threshold. If embolising vessels produced the recorded $A E$ on 30 May, then perhaps they were more vulnerable than those embolised on the following day. Thus, the relationship between $\mathrm{AE}$ rate and $\Psi$ need not be unique but may depend on the previous history of stress and the vulnerability index of vessels, which in oak is probably related to vessel diameter. It is also possible that AEs reflect events other than xylem cavitations (Jones and Peña, 1986; Ritman and Milburn, 1991). The relationships of $A E$ detected in oak seedlings to cavitations and hydraulic conductance are uncertain. The AE method, therefore, does not provide a suitable noninvasive alternative to hydraulic conductivity vulnerability curves for comparing drought susceptibility between species of the types examined here.

Although $\Psi$ for young seedlings in the field may not often reach the point at which embolism becomes damaging, this may not be the case in very dry seasons or when seedlings are allowed to desiccate prior to 
planting, due to delay or mishandling. Losses could then be considerable due to xylem dysfunction not only in the leafless stem but in the few roots that remain after the seedling has been transplanted. Therefore, knowledge of differences in drought susceptibility between species may enable better management techniques to be introduced and, eventually, provide strategies for breeding superior and rugged trees that are able to withstand such stresses.

\section{ACKNOWLEDGMENTS}

Thanks are due to the Ministry of Agriculture, Fisheries and Food and the CEC STEP-CT900050-C(DSCN) who provided the funds to finance this project. Thanks also to Dr E Dreyer, INRA, Nancy, France who provided seeds of $Q$ robur, $Q$ petraea and $Q$ pubescens.

\section{REFERENCES}

Borghetti M, Raschi A, Grace J (1989) Ultrasound acoustic emission in water-stressed plants of Picea abies Karst. Ann Sci For 46 (suppl) 346s-349s; For Tree Physiol (E Dreyer et al, eds)

Bréda N, Cochard H, Dreyer E, Garnier A (1993) Field comparison of transpiration, stomatal conductance and vulnerability to cavitation of Quercus petraea and Quercus robur under water stress. Ann Sci For $50,571-582$

Cochard H, Breda N, Granier A, Aussenac G (1992) Vulnerability to air embolism and hydraulic architecture of 3 European oak species. Ann Sci For 49, 225-233

Cox DR, Snell EJ (1989) Analysis of binary data. 2nd edition, Chapman \& Hall, London, $236 p$

Day $W$ (1977) A direct reading continuous-flow porometer. Agric Meteorol 18, 81-89

Delatour C (1990) Oak decline and the status of Ophiostoma spp on oak in Europe - France. Bull OEPP/EPPO Bull 20, 408-409

Dixon MA, Grace J, Tyree MT (1984) Concurrent measurements of stem density, leaf and stem water potential, stomatal conductance and cavitation on a sapling of Thuja occidentalis L. Plant Cell Environ $7,615-618$

Grieg BJW (1992) Occurrence of decline and dieback of oak in Great Britain. For Comm Res Info Note 214

Higgs $\mathrm{KH}$, Jones $\mathrm{HG}$ (1984) A microcomputer-based system for continuous measurement and recording fruit diameter in relation to environmental factors. $J$ Exp Bot 35, 1646-1655

Hull SK, Gibbs JN (1991) Ash dieback - a survey of non-woodland trees. For Comm Bull 93, HMSO, London

Jones HG, Peña J (1986) Relationships between water stress and ultrasound emission in appel (Malus $\mathrm{X}$ domestica Borkh). J Exp Bot 37, 1245-1254

Jones $H G$, Sutherland RA (1991) Stomatal control of xylem embolism. Plant Cell Environ 14, 607-612

OEPP/EPPO (1990) Oak decline and the status of Ophiostoma spp on oak in Europe. Bull OEPP/EPPO Bull 20, 405-422

Ritman KT, Milburn JA (1991) Monitoring of ultrasound and audible emissions from plants with or without vessels. J Exp Bot 42, 123-130

Sandford AP, Grace J (1985) The measurement and interpretation of ultrasound from woody stems. J Exp Bot 36, 298-311

Sperry JS, Donnelly JR, Tyree MT (1988a) A method for measuring hydraulic conductivity and embolism in xylem. Plant Cell Environ 11, 35-40

Sperry JS, Donnelly JR, Tyree MT (1988b) Seasonal occurrence of xylem embolism in sugar maple (Acer saccharum). Am J Bot 75, 1212-1218

Sperry JS, Pockman WT (1993) Limitation of transpiration by hydraulic conductance and xylem cavitation in Betula occidentalis. Plant Cell Environ 16, 279287

Sperry JS, Sullivan JEM (1992) Xylem embolism in response to freeze-thaw cycles and water stress in ring-porous, diffuse-porous, and conifer species. Plant Physiol 100, 605-613

Tyree MT, Sperry JS (1989) Vulnerability of xylem to cavitation and embolism. Ann Rev Plant Physiol Mol Biol $40,19-38$

Tyree MT, Alexander J, Machado JL (1992) Loss of hydraulic conductivity due to water stress in intact juveniles of Quercus rubra and Populus deltoides. Tree Physiol 10, 411-415

Vannini A, Scarascia Mugnozza G (1991) Water stress: a predisposing factor in the pathogenesis of HypoxyIon mediterraneum on Quercus cerris. Europ J For Path 4, 193-202 